\title{
Correction to: Serum levels of sclerostin reflect altered bone microarchitecture in patients with hepatic cirrhosis
}

\author{
Robert Wakolbinger - Christian Muschitz (D) - Jacqueline Wallwitz - Gerd Bodlaj - Xaver Feichtinger • \\ Jakob E. Schanda · Heinrich Resch · Andreas Baierl · Peter Pietschmann
}

Published online: 3 February 2020

(C) The Author(s) 2020

\section{Correction to: \\ Wien Klin Wochenschr 2019 \\ https://doi.org/10.1007/s00508-019-01595-8}

The original version of this article unfortunately contained a mistake. The last sentence should read: Patients with ALD had significantly lower sclerostin levels, compared to controls. The authors apologize for the mistake.

Open Access This article is licensed under a Creative Commons Attribution 4.0 International License, which permits use, sharing, adaptation, distribution and reproduction in any medium or format, as long as you give appropriate credit to the original author(s) and the source, provide a link to the Creative Commons licence, and indicate if changes were made. The images or other third party material in this article

The online version of the original article can be found under https://doi.org/10.1007/s00508-019-01595-8.

\section{R. Wakolbinger, M.D.}

Department of Physical and Rehabilitation Medicine,

Danube Hospital - Social Medical Center East, Academic Teaching Hospital of the Medical University of Vienna, Langobardenstraße 122, 1220 Vienna, Austria

R. Wakolbinger, M.D. .

Associate Professor C. Muschitz, M.D. (西) ·

Associate Professor G. Bodlaj, M.D. · X. Feichtinger, M.D.,

Ph.D. · J. E. Schanda, M.D. · Professor H. Resch, M.D.

Medical Department II - The VINFORCE Study

Group, St. Vincent Hospital, Academic Teaching

Hospital of the Medical University of Vienna,

Stumpergasse 13, 1060 Vienna, Austria

christian.muschitz@bhs.at

J. Wallwitz, Ph.D.

The Antibody Lab, Divischgasse 4, 1210 Vienna, Austria

Division of Pharmacology, Department of Pharmacology, Physiology and Microbiology, Karl Landsteiner University of Health Sciences, Dr.-Karl-Dorrek-Straße 30, 3500 Krems, Austria are included in the article's Creative Commons licence, unless indicated otherwise in a credit line to the material. If material is not included in the article's Creative Commons licence and your intended use is not permitted by statutory regulation or exceeds the permitted use, you will need to obtain permission directly from the copyright holder. To view a copy of this licence, visit http://creativecommons.org/licenses/by/4.0/.

X. Feichtinger, M.D., Ph.D. · J. E. Schanda, M.D.

AUVA Trauma Center Meidling,

Kundratstraße 37, 1120 Vienna, Austria

Professor H. Resch, M.D.

Karl Landsteiner Institute for Gastroenterology and Rheumatology, Stumpergasse 13, 1060 Vienna, Austria

A. Baierl, Ph.D.

Department of Statistics and Operations

Research, University of Vienna,

Oskar-Morgenstern-Platz 1, 1090 Vienna, Austria

Professor P. Pietschmann, M.D.

Department of Pathophysiology and Allergy Research,

Center for Pathophysiology, Infectiology and Immunology,

Medical University of Vienna, Währinger Gürtel

18-20, 1090 Vienna, Austria 